\title{
Conceitos es práticas na educaÇão de alunos COM altas HABILIDADES/SUPERDOTAÇÃO
}

Denise deSouza FLEITH ${ }^{1}$

FREITAS, Soraia N apoleão (Org.). Edu cação eal tas habilidades/superdotação: aousadia derever conceitos e práticas. Santa Maria: Editora UFSM , 2006. 277p.

A pesar do crescente reconhecimento, no cenário nacional e internacional, da importância de se criar condições favoráveis ao desenvolvimento do potencial de indivíduos com altas habilidades/ superdotação, observa-se que pouco se conhece acerca das suas necessi dades ecaracterísticas. A demais, noções falsas sobre estes indivíduos, fruto de preconceito e desinformação, estão profundamenteenraizadas no pensamento popular, interferindo edificultando a implantação depráticas educacionais queatendam aos anseios enecessidades deste grupo. O livro organizado por Soraia Napoleão de Freitas brinda o leitor com informações atual izadas efundamentadas, teórica eempiricamente, sobre diversas dimensões do fenômeno das altas habilidades/ superdotação, contribuindo para desmistificar muito das idéias estereotipadas acerca do aluno superdotado veiculadas em nossa sociedade.

A obra éconstituída de prefácio, introdução e 12 capítulos e conta com a colaboração de 13 estudiosos de instituições do Rio Grande do Sul eda A rgentina. O prefácio éelaborado por Joseph Renzulli, diretor do Centro Nacional de Pesquisa sobre o Superdotado e Tal entoso da Universidade de Connecticut, nos Estados Unidos, e eminente pesquisador da área. É destacada no prefácio a abordagem educacional, adotada no livro, quefocaliza na maximização do potencial decada aluno como aprendiz e produtor criativo. Ademais Renzulli chama atenção para o fato de que várias práticas implementadas na educação do superdotado têm sido utilizadas na educação em geral. A seguir, na introdução, são apresentados dois reconhecidos referenciais teóricos na área - A Teoria das Inteligências Múltiplas, proposta por Gardner, e a Teoria dos Três A néis, elaborada por Renzulli -, que embasam ações e projetos de pesquisa desenvolvidos no Rio Grande do Sul.

Diversos temas sobrealtas habilidades/ superdotação são contemplados nos capítul os seguintes. Uma parte destes capítulos analisa diversas concepções

${ }^{1}$ Professora do Programa de Pós-graduação em Processos de Desenvolvimento Humano eSaúde do I nstituto dePsicologia da Universidade deBrasília - fleith@unb.br 
sobrealtas habilidades/ superdotação, clarifica conceitos eterminologias, além de desmistificar idéias errôneas veiculadas acerca do indivíduo com altas habilidades. Outra parte dos capítulos examina características do indivíduo superdotado na infância e na adolescência e propõe uma estratégia de identificação na Educação Infantil. Dois capítulos focalizam questões legais relacionadas à educação do superdotado. Um analisa as políticas públicas educacionais para o aluno superdotado no Rio Grande do Sul eo outro apresenta a legisl ação, especial mente das duas últimas décadas, que dá suporteao atendimento ao aluno superdotado em estados da região sul do Brasil . Final mente, quatro capítulos discutem práticas eprogramas deatendimento tanto ao al uno com al tas habilidades/ superdotação quanto às suas famílias à luz dos princípios da educação inclusiva.

Podemos então conduir queestelivro éuma fonte desubsídios valiosos ao profissional interessado em desenvolver práticas educacionais que estimulem o desenvolvimento criativo, saudável esingular do aluno com altas habilidades/ superdotação e oportunizem experiências de aprendizagem prazerosa considerando seus interesses, estilos de expressão e habilidades. É importante lembrar que um potencial não cultivado é um potencial perdido. Assim, o aluno com altas habilidades/ superdotação necessita de uma variedade deexperiências de aprendizagem enriquecedoras queestimulem o seu desenvolvimento cognitivo, emocional e social, favorecendo a realização plena de seu potencial. A lém disso, estelivro convida o leitor a refletir sobre avanços conquistados edesafios a serem superados em rel ação à educação do al uno com altas habilidades/ superdotação. 